\title{
Evaluation of the net energy value of glucose (cerelose) and maize starch in diets for rainbow trout (Salmo gairdneri)
}

\author{
BY JOHN W. HILTON ${ }^{1}$, JAMES L. ATKINSON ${ }^{2}$ \\ AND STANLEY J. SLINGER ${ }^{1}$ \\ ${ }^{1}$ Department of Nutritional Sciences and ${ }^{2}$ Department of Animal and Poultry Science, \\ University of Guelph, Guelph, Ontario NIG $2 W 1$, Canada
}

(Received 11 September 1986 - Accepted 8 June 1987)

1. Quadruplicate groups of rainbow trout (Salmo gairdneri) (mean body-weight $24.9 \mathrm{~g}$ ) were reared on six dietary treatments (practical-type diets) in a modified paired-feeding experiment for 12 weeks at $15^{\circ}$ to determine the net energy (NE) value of starch and glucose to rainbow trout.

2. Three test diets were prepared to contain $(\mathrm{g} / \mathrm{kg}): 0$ supplemented carbohydrate (diet 1 ), 250 maize starch (diet 2) and 250 glucose (diet 3 ) and were given ad lib. to the trout with the feeding rate of the glucose- and starchfed groups being monitored after each feeding. The remaining three treatments involved controlled feeding of the trout with diet 1 at $75 \%$ of the feed intake of trout reared on diets 2 and 3, so as to provide the same levels of protein and lipids without carbohydrate, and with diet 2 at $100 \%$ of the feed intake of trout reared on diet 3 .

3. The difference in the final carcass energy of the ad lib.-fed group and the respective controlled-fed group divided by the amount of dietary glucose or starch energy consumed by the trout is the NE value for that carbohydrate.

4. The determined NE value of glucose was $3.99 \mathrm{~kJ} / \mathrm{g}$ and starch $2 \cdot 17 \mathrm{~kJ} / \mathrm{g}$, which is 24.6 and $12.6 \%$ respectively of the gross energy values of these carbohydrates in rainbow trout.

5. The results indicate that digestible energy and calculated metabolizable energy values for carbohydrates in rainbow trout overestimate the utilizable energy content of the diet.

6. The determined NE values for glucose and starch in the present study should be used with caution since various factors (such as the feeding rate determined in the present study) may affect the utilization of dietary carbohydrates in rainbow trout.

The natural diet of a carnivorous fish such as the rainbow trout (Salmo gairdneri) contains little carbohydrate and therefore the ability of the trout to utilize this source of dietary energy may be limited. Nevertheless, when formulating commercial diets, it has been deemed necessary, and desirable as a cost-effective measure, to have a significant amount of carbohydrate in the diet. However, there is considerable controversy regarding the optimum level of digestible carbohydrates in a salmonid diet. Research in our laboratory (Hilton \& Atkinson, 1982) has indicated that digestible carbohydrates in excess of $140 \mathrm{~g} / \mathrm{kg}$ diet cannot be efficiently utilized by salmonids, which is consistent with the results of Phillips et al. (1948). However, this conclusion is in contrast to the conclusions of Buhler \& Halver (1961), Luquet (1971) and Bergot (1979) who suggest that levels of $200 \mathrm{~g} / \mathrm{kg}$ diet or higher are effectively utilized.

There is also some debate as to the energy value assigned to carbohydrates in a fish diet (Jobling, 1983). For salmonids the digestibility of different types of carbohydrates varies with complexity of carbohydrate structure (Singh \& Nose, 1967; Phillips, 1969; Smith, 1971), concentrations in the diet (Takeuchi et al. 1979; Bergot \& Breque, 1983; Spannhof \& Plantikow, 1983), source and diet processing (Hilton et al. 1981; Hilton \& Slinger, 1983), and the species of fish (Jobling, 1983). Furthermore, test diets with approximately the same digestible energy (DE) content and level of protein, but with varying amounts of glucose or fat, do not always produce the same growth results and carcass composition in trout (Hilton \& Atkinson, 1982; Beamish et al. 1986). Therefore, the use of DE values as they pertain to carbohydrates may overestimate the utilizable or productive energy content of the diet. Similarly, the use of calculated metabolizable energy (ME) values of different 
carbohydrates is fraught with errors and assumptions which makes their use very unreliable (Jobling, 1983). Furthermore, the procedures used in determining actual ME values for feedstuffs or diets (force-feeding, restraint, etc.) may result in stress and negative nitrogen balance which reduces the usefulness of this measurement (Cho et al. 1982). In addition, the use of fish metabolism chambers to determine $\mathrm{ME}$ values of feedstuffs can only be applied to large fish (165-530 g, Smith, 1971). Nevertheless, there is a need to determine the productive energy value of different types of carbohydrates in commercial trout diets.

In the past, poultry nutritionists have used productive energy measurements as an estimate of the net energy (NE) in order to describe the utilizable energy in feedstuffs ((US) National Research Council, 1981). Fraps \& Carlyle (1942) defined productive energy as the energy stored as fat and protein from the portion of the ration eaten which exceeds the quantity used for maintenance purposes. Presumably, the amount of energy stored as glycogen is not considered to be a significant store by this definition, and in any case would also be measured by bomb calorimetry of the final carcass. Therefore, it should be possible to estimate the NE value of carbohydrates by measuring the extra energy retained by fish consuming diets which have the same nutrient composition with the exception of the carbohydrate content.

The purpose of the present study was to estimate the NE value of glucose (cerelose) and raw maize starch in a trout diet when included at a level of $250 \mathrm{~g} / \mathrm{kg}$ diet.

\section{METHODS \\ Experimental design}

A modified paired-feeding experiment involving six dietary treatments was conducted using quadruplicate groups of rainbow trout reared at $15^{\circ}$ in a completely randomized design. Three test diets formulated to contain $(\mathrm{g} / \mathrm{kg})$ : 0 supplemented carbohydrate (diet 1$), 250$ raw maize starch (diet 2) and 250 glucose (cerelose, diet 3), were given ad lib. to the trout with the feed intake of trout reared on the starch (diet 2) and glucose (diet 3) diets being monitored after each feeding. The remaining three dietary treatments involved controlled feeding of trout at levels derived from the ad lib. intakes. Thus, diet 1 was also given to trout at $75 \%$ of the feed intake of those reared on either diet 2 (starch, diet $1 \mathrm{~A}$ ) or diet 3 (glucose, diet 1 B) thereby giving the trout similar amounts of protein and lipid as fish fed on diets 2 and 3 , but without additional carbohydrate. In addition, diet 2 (starch) was also given to trout at the same feed intake as those reared on diet 3 (glucose, diet $2 \mathrm{~A}$ ). After 12 weeks on the test diets the growth variables, liver:body-weight, liver glycogen content, carcass composition and NE value of the starch and glucose were determined.

\section{Diet formulation, processing and analysis}

Three test diets were formulated as described in Table 1 and processed by steam pelleting on a laboratory pellet mill. After processing, the test diets were analysed for ash, energy, moisture and protein content as described by Horwitz (1980), lipid content as described by Bligh \& Dyer (1959), glucose content as described by Hilton et al. (1983) and starch content as described by Clegg (1956).

\section{Supply and maintenance of fish}

Rainbow trout were obtained from a commercial fish farmer and adjusted to laboratory conditions for approximately 10 weeks. After the adjustment period, 720 fish were transferred to a twenty-four tank aquatic system. The aquaria were circular enamel-lined metal tanks (capacity 65 litres), individually aerated and thermostatically maintained at 
$15.3 \pm 0.4^{\circ}$ on a biological filtration system with $5-20 \%$ daily replacement water. The $\mathrm{pH}$ varied between 7.6 and 7.8 , dissolved oxygen between 6.2 and $8.1 \mathrm{mg} / 1$ and total ammonia (Nessler's reagent) between 0.01 and $1.10 \mathrm{mg} / 1$ throughout the study. The initial weight of the fish was $2.9 \mathrm{~g}$ and the fish were fed three to four times per d either to satiety, as described by Hilton \& Slinger (1981), or to the previously described modified paired-feeding rate. Before the start of the growth study, two fish were removed from each tank, anaesthetized with tricaine methane sulphonate (MS 222), killed, ground, freeze-dried and stored at $-20^{\circ}$ until required for analysis.

\section{$D E$ determination}

A digestibility study was conducted as described by Hilton \& Slinger (1986) in which triplicate groups of thirty fish/tank (mean body-weight $65 \mathrm{~g}$ ) were reared on the test diets. Faeces were collected by the gravity faeces collection technique as described by Cho et al. (1982), freeze-dried, ground and stored in a cooler at $-50^{\circ}$ until required for analysis. The acid-insoluble ash contents for the test diets and faeces were determined as described by Atkinson et al. (1984) and the moisture and energy contents of the diet and faeces determined by bomb calorimetry as described by Horwitz (1980).

\section{Growth and biochemical analysis}

The trout were weighed after every 4-week period and recounted and weighed at the end of 12 weeks. Mortalities and feed consumption were noted daily and feed:gain ratios determined at the end of each period. At the end of 12 weeks and $18 \mathrm{~h}$ after the last feeding, four fish were sampled at random from each tank of diets 1,2 and 3 and immediately anaesthetized with MS 222 . The fish were then individually weighed, livers removed and weighed and the livers then frozen in liquid $\mathrm{N}_{2}$ and stored at $-20^{\circ}$ until required for analysis. The glycogen content of the liver was determined as described by Murat \& Serfaty (1974). A further four fish that were fasted for $24 \mathrm{~h}$ were then sampled at random from each tank, anaesthetized with MS 222, killed by severing the spinal cord behind the head, ground and reground with a meat grinder, frozen, freeze-dried and reground in a Waring blender and stored at $-20^{\circ}$ until required for analysis. The initial and final fish carcasses were analysed for ash, moisture, protein and energy content as described by Horwitz (1980), and lipid content as described by Bligh \& Dyer (1959).

\section{Calculation of $N E$}

On the basis of final body-weight (Table 2), carcass composition and energy content (Table 3 ), the total carcass energy of the fish on the different dietary treatments was determined. The difference in total carcass energy of the trout reared on the starch or glucose diets (diets 2 and 3 ) and the total carcass energy of the fish in the respective modified pair-fed groups reared on the control diet (diet 1) is that supplied by the glucose or starch supplement. The amount of starch and glucose energy consumed by the fish was determined by multiplying the measured feed consumption per fish (mean of four replicates) by the starch and glucose contents of test diets 2 (starch) and 3 (glucose, Table 1) as appropriate. The assigned energy value of glucose was $15.9 \mathrm{~kJ} / \mathrm{g}$ and the starch $17.2 \mathrm{~kJ} / \mathrm{g}$. The $\mathrm{NE}$ of glucose or starch was then calculated as described in Table 4.

\section{Statistical analysis}

The results were subjected to analysis of variance and, where applicable, differences determined at $P<0.05$ using Tukey's Honestly Significant Difference Procedures as outlined by Steel \& Torrie (1980). 
Table 1. Formulation, composition and digestible energy value of the test diets

\begin{tabular}{|c|c|c|c|c|}
\hline Diet no.... & 1 & 2 & 3 & \\
\hline \multicolumn{5}{|l|}{ Ingredients (g/kg) } \\
\hline Capelin meal & 466 & 350 & 350 & \\
\hline Soya-bean meal & 267 & 200 & 200 & \\
\hline Wheat gluten & 67 & 50 & 50 & \\
\hline Wheat middlings & 40 & 30 & 30 & \\
\hline Bentonite & 26 & 20 & 20 & \\
\hline Vitamin premix $\dagger$ & 26 & 20 & 20 & \\
\hline Mineral premix $\dagger$ & 13 & 10 & 10 & \\
\hline Cerelose (D-glucose) & - & - & 250 & \\
\hline Maize starch & - & 250 & - & \\
\hline Fish oil & 95 & 70 & 70 & \\
\hline Analyses $\ddagger(\mathrm{g} / \mathrm{kg})$ & Mean & Mean & Mean & SE \\
\hline Protein & 493 & 388 & 385 & - \\
\hline Lipid & 136 & 106 & 111 & - \\
\hline Ash & 121 & 91 & 92 & - \\
\hline Glucose & trace & trace & 242 & - \\
\hline Starch & 51 & 281 & 31 & - \\
\hline Digestible energy $(\mathrm{kJ} / \mathrm{g})$ & $19 \cdot 8^{\mathrm{a}}$ & $18 \cdot 1^{\mathrm{b}}$ & $18 \cdot 7^{\mathrm{c}}$ & $0 \cdot 12$ \\
\hline Calculated metabolizable energy§ $(\mathrm{kJ} / \mathrm{g})$ & $12 \cdot 9$ & $11 \cdot 7$ & $14 \cdot 0$ & - \\
\hline
\end{tabular}

$a, b, c$ Values in horizontal rows with unlike superscript letters were significantly different: $P<0 \cdot 05$.

$\dagger$ As described in Hilton \& Slinger (1981).

$\$$ Values are the means of three samples per diet expressed on a dry matter basis.

$\S$ Based on $(\mathrm{kJ} / \mathrm{g}) 16.3$ protein, 33.4 lipid, 6.7 starch, $15 \cdot 7$ glucose.

\section{RESULTS \\ Digestibility study}

The digestibility study indicated that all three diets had significantly different $\mathrm{DE}$ values (Table 1 ) with diet 1 having the highest DE $(19 \cdot 8 \mathrm{~kJ} / \mathrm{g})$ and diet 2 the lowest DE $(18 \cdot 1 \mathrm{~kJ} / \mathrm{g})$. However, it should be noted that the determined DE value of the starch diet (diet 2) was higher than would be predicted on the basis of the theoretical digestibility of starch in this fish $(16.5 \mathrm{~kJ} / \mathrm{g})$. The faeces in the present study were collected by the gravity faeces collection system and therefore the faeces could potentially be in contact with water for up to $18 \mathrm{~h}$. As noted by Windell et al. (1978) this can significantly increase the leaching losses from the faeces, particularly if the faeces contain large amounts of partially digested carbohydrates (Spannhof \& Plantikow, 1983) as in diet 2. Therefore, the determined DE value of the starch diet (diet 2 ) in the present study may not be an accurate assessment.

\section{Growth and biochemical analysis}

The final feed intakes of the modified pair-fed groups, diets $1 \mathrm{~A}$ and $1 \mathrm{~B}$, were 75.4 and $74.8 \%$ respectively of the feed intake of trout fed on diets 2 and 3 . After 12 weeks on the test diets, the trout reared ad lib. on the control (diet 1) and starch (diet 2) diets had a significantly higher final body-weight than trout reared on the glucose $\operatorname{diet}(\operatorname{diet} 3$, Table 2). Trout reared on the modified pair-fed control diet (diets $1 \mathrm{~A}$ and $1 \mathrm{~B}$ ) had a significantly lower final body-weight than trout reared on the corresponding starch or glucose diets. However, trout reared on the starch-based diet fed at the same rate as that of the glucosefed trout (diet 3) had essentially the same final body-weight (Table 2). There was no significant difference in the feed:gain ratios of the trout reared on any of the control diets (diets 1, 1 A and 1B) and these were significantly lower than the feed:gain ratios of trout 


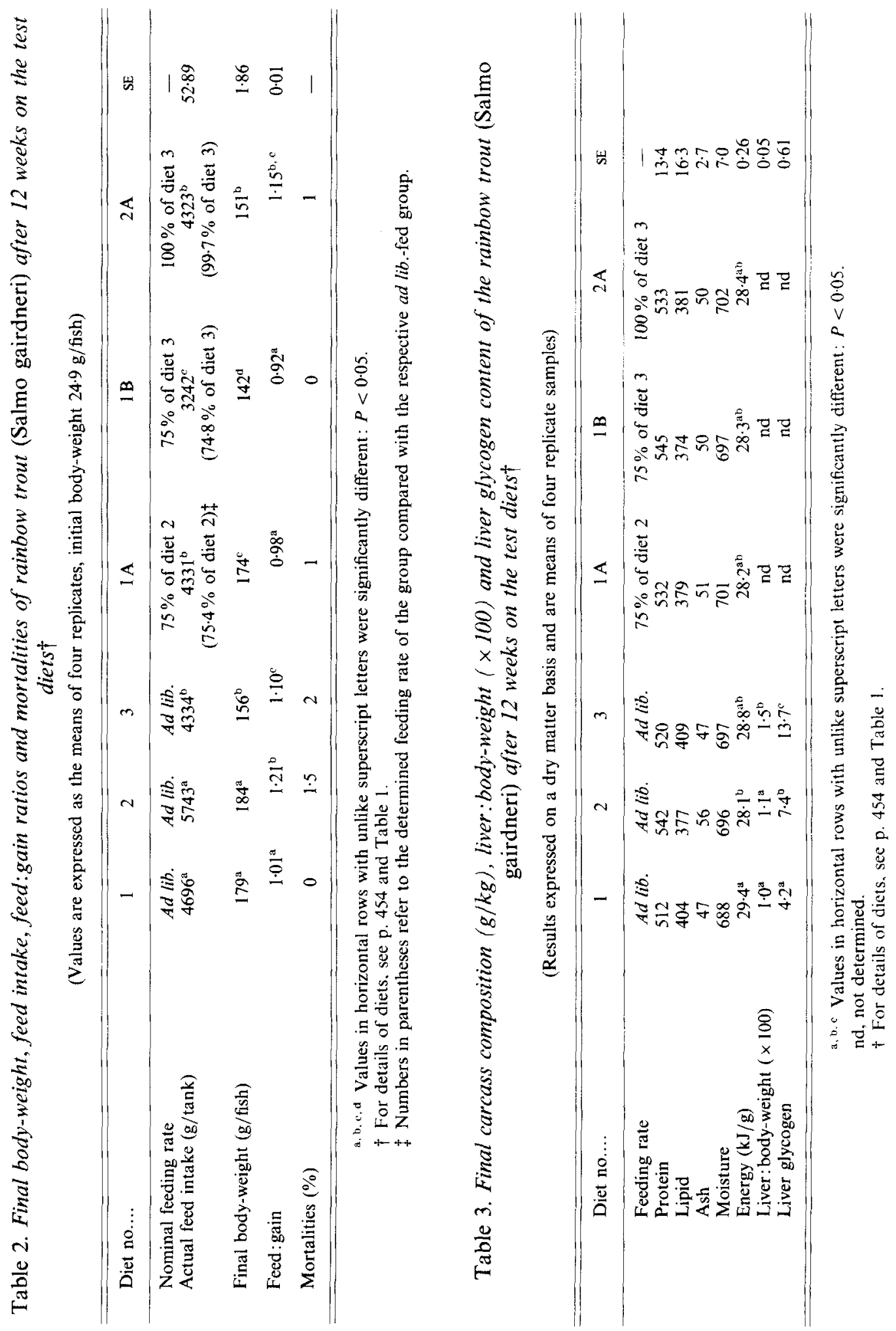


Table 4. Calculation of the net energy (NE) of consumed starch and glucose in rainbow trout (Salmo gairdneri)

\begin{tabular}{|c|c|}
\hline \multicolumn{2}{|l|}{ Starch } \\
\hline Final total carcass energy of starch group (diet 2 ) & $1571.8 \mathrm{~kJ} / \mathrm{g}$ \\
\hline $\begin{array}{l}\text { Final total carcass energy, diet } 1 \mathrm{~A} \\
\text { (modified pair-fed) }\end{array}$ & $1467 \mathrm{~kJ} / \mathrm{g}$ \\
\hline $\begin{array}{l}\text { Difference in retained carcass energy } \\
\text { (carcass energy gained diet } 2 \text { - diet } 1 \text { A) }\end{array}$ & $104 \cdot 8 \mathrm{~kJ}$ \\
\hline Amount of feed consumed per fish & $193 \mathrm{~g}$ \\
\hline Amount of starch consumed per fish & $48 \cdot 3 \mathrm{~g}$ \\
\hline $\begin{array}{l}\text { Amount of starch-energy consumed per fish } \\
\begin{aligned} \text { NE of starch } & =(104.8 \div 830) \times 100 \\
& =12.6 \% \text { of starch energy } \\
& =2.17 \mathrm{~kJ}(0.52 \mathrm{kcal}) / \mathrm{g} \text { starch }\end{aligned}\end{array}$ & $830 \mathrm{~kJ}$ \\
\hline \multicolumn{2}{|l|}{ Glucose } \\
\hline Final total carcass energy of glucose group (diet 3 ) & $1361.3 \mathrm{~kJ} / \mathrm{g}$ \\
\hline $\begin{array}{l}\text { Final total carcass energy, diet IB } \\
\text { (modified pair-fed) }\end{array}$ & $1217.6 \mathrm{~kJ} / \mathrm{g}$ \\
\hline $\begin{array}{l}\text { Difference in retained carcass energy } \\
\text { (carcass energy gained diet } 3 \text {-diet } 1 \mathrm{~B} \text { ) }\end{array}$ & $143.7 \mathrm{~kJ}$ \\
\hline Amount of feed consumed per fish & $145 \mathrm{~g}$ \\
\hline Amount of glucose consumed per fish & $36 \cdot 1 \mathrm{~g}$ \\
\hline $\begin{array}{l}\text { Amount of glucose-energy consumed per fish } \\
\begin{aligned} \text { NE of glucose } & =(143.7 \div 584) \times 100 \\
& =24.6 \% \text { of glucose energy } \\
& =3.99 \mathrm{~kJ}(0.95 \mathrm{kcal}) / \mathrm{g} \text { glucose }\end{aligned}\end{array}$ & $584 \mathrm{~kJ}$ \\
\hline
\end{tabular}

reared on the glucose or starch diets (diets 2, 3 and 2A). Trout reared on the starch diet (diet 2) had a significantly higher feed:gain ratio than trout reared on the glucose diet (diet 3). Trout reared on the starch diet pair-fed to the feeding rate of trout fed on the glucose diet had a feed:gain ratio intermediate to that of the ad lib. starch- or glucose-fed fish (diet $2 \mathrm{~A}$, Table 2). Mortalities were uniformly low $(<2 \%)$ and were not apparently related to either dietary treatment or feeding regimen.

Final carcass analysis indicated that the fish fed on the various test diets had essentially the same carcass composition and energy content with the exception that trout reared on the starch diet (diet 2) had a significantly lower final carcass energy than trout reared on diet 1 (Table 3). Trout reared on the glucose diet (diet 3 ) had a significantly higher liver weight : body-weight ratio and liver glycogen content than trout reared on either the control or starch diets (Table 3). In addition, trout reared on the starch diet (diet 2) had a significantly higher liver glycogen content than trout reared on the control diet (diet 1).

\section{NE of starch and glucose}

The calculations used to determine the NE for starch and glucose are outlined in Table 4. Based on the assumption that the gross energy of glucose was $16.2 \mathrm{~kJ} / \mathrm{g}$ and starch 17.2 $\mathrm{kJ} / \mathrm{g}$, the calculated $\mathrm{NE}$ for glucose was $3.99 \mathrm{~kJ} / \mathrm{g}$ glucose and for starch $2.17 \mathrm{~kJ} / \mathrm{g}$ starch.

\section{DISCUSSION}

The results of the present study indicate that the NE of glucose and raw maize starch in a practical-type diet provided 3.99 and $2.17 \mathrm{~kJ} / \mathrm{g}$ respectively to rainbow trout when included at $250 \mathrm{~g} / \mathrm{kg}$ diet. The NE values were approximately $25 \%$ of the glucose and $13 \%$ of the starch gross energy values for these compounds in trout (Table 5). This partially explains 
Table 5. The gross energy $(G E)$, digestible energy $(D E)$, metabolizable energy $(M E)$ and net energy $(N E)$ of glucose and raw maize starch in rainbow trout (Salmo gairdneri) $(\mathrm{kJ} / \mathrm{g}$ )

\begin{tabular}{lcc}
\hline & Glucose & Maize starch \\
\hline GE & $15 \cdot 9$ & $17 \cdot 2$ \\
DE* & $15 \cdot 7$ & $6 \cdot 9$ \\
ME $\dagger$ & $15 \cdot 7$ & $6 \cdot 7$ \\
NE $\ddagger$ & 3.99 & $2 \cdot 17$ \\
NE as a percentage of GE & $25 \cdot 1$ & 12.6 \\
\hline
\end{tabular}

* Assuming that the digestibility of glucose is 0.99 and raw maize starch is 0.40 .
+ Phillips (1972).
$\ddagger$ Present study.

why the present and previous studies in this laboratory have indicated that the determined $\mathrm{DE}$ or calculated ME levels of test diets, as indicated in Table 1, containing significant levels of carbohydrates overestimates the productive energy value of those diets (Hilton et al. 1981, 1982; Hilton \& Atkinson, 1982; Beamish et al. 1986). Why the absorbed glucose from cerelose or raw maize starch does not supply the expected source of energy cannot be determined from the present study. However, oral glucose tolerance in the trout is poor and this indicates a poor or impaired metabolic utilization of the absorbed glucose by the trout (Palmer \& Ryman, 1972; Hilton, 1982).

Although the determined NE value of glucose was higher than that of starch, the final body-weight of trout given the starch diet ad lib. was significantly higher than that of trout fed on the glucose diet ad lib. In contrast, trout fed on the control or starch diets grew equally well (Table 2). To maintain this growth rate, the fish on the starch diet ate approximately $1000 \mathrm{~g}$ feed/tank more than the control group. Since the digestibility of raw maize starch would be no more than $40 \%$ (Phillips, 1969; Smith, 1971), the remainder of the undigested starch could act as a bulk factor, increasing the feed intake of the trout as they sought to achieve an appropriate level of nutrient intake. Previous studies in our laboratory have indicated that increasing the undigestible bulk or fibre content of diets increases feed consumption by trout (Hilton et al. 1983). Similarly, Kaushik \& de Oliva Teles (1985) showed that trout fed on diets containing either gelatinized or natural starch were able to grow equally well as the result of increased feed intake in those fish fed on the less digestible natural starch diet. The poorer growth of trout fed on the glucose diet compared with both the control and starch-based diets in the present study (Table 2) implies that this compensatory intake response is not always operative. If it were, fish fed on the glucose-containing diet should have grown as well as the starch-fed fish, while consuming less diet. Although they did eat approximately $1400 \mathrm{~g}$ feed/tank less, this was also over $460 \mathrm{~g} /$ tank less than the control fish consumed (Table 2) and this reduced intake contributed to depressed growth rate. A reduced feeding response in consecutive daily feedings of trout reared on diets high in available carbohydrate has been observed consistently in both the present and previous studies conducted in our laboratory (Hilton et al. 1981; Hilton \& Atkinson, 1982; Hilton \& Slinger, 1983). It has been suggested that the poor glucose tolerance and prolonged hyperglycaemia induced by such diets may affect some sort of glucostatic receptors in the trout, thus reducing appetite or feeding response. Interestingly, recent work with channel catfish has indicated that a diet containing glucose as the carbohydrate source leads to growth depression when compared with a starch-based diet (Wilson \& Poe, 1987). It is obvious that we require a greater understanding of the physiological role of dietary glucose in fish. 
On the basis of the results of the present study, the utilization of the DE or calculated $M E$ values of carbohydrates as a basis for determining or calculating the utilizable energy content of a trout diet should be discontinued. However, caution should be used in applying the NE values of the glucose and starch determined in the present study. Productive energy values in poultry are not always additive (Davidson et al. 1957; Hill \& Andersen, 1958). Furthermore, the utilization of glucose as an energy source in trout appears to depend on a number of factors such as the alternative energy sources in the diet (Hilton et al. 1982) and the protein content of the diet (Bergot, 1979). For example, there was no significant difference in the final body-weight or carcass composition of trout reared on diet 3 (glucose) and diet $2 \mathrm{~A}$, the pair-fed starch group (Table 2). The calculated NE value of the starch using the results of the pair-fed group, diet $2 \mathrm{~A}$, was $3.85 \mathrm{~kJ} / \mathrm{g} \mathrm{starch}$, which is much higher than that determined for starch in the ad lib.-fed group (diet 2, $2.17 \mathrm{~kJ} / \mathrm{g}$ starch, Table 4). Therefore, the feeding rate of the fish must affect the NE value or the utilizable energy derived from dietary carbohydrates. In addition, since the level of complex carbohydrates in a diet, the type or amount of diet, and the processing of carbohydrate may affect carbohydrate digestibility (Takeuchi et al. 1979; Hilton et al. 1981; Hilton \& Slinger, 1983; Spannhof \& Plantikow, 1983), these factors would also affect the NE value of the carbohydrate. Therefore, it is probable that no fixed or universally applicable NE value can be assigned to glucose or starch in the trout diet. However, further studies on the effect of dietary energy and protein content and the level of different types of carbohydrates in the trout diet are required in order to produce a range of values for the NE of specific carbohydrates in the trout.

The authors wish to thank Ms Debbie Conrad and Mr Marty Hodgson for technical support, Hoffmann-La Roche Canada for generously donating the vitamins used in the study, and the Ontario Ministry of Agriculture and Food and the Natural Sciences and Engineering Research Council for financial support.

\section{REFERENCES}

Atkinson, J. L., Hilton, J. W. \& Slinger, S. J. (1984). Canadian Journal of Fisheries and Aquatic Sciences 41, 1384-1386.

Beamish, F. W. H., Hilton, J. W., Niimi, E. \& Slinger, S. J. (1986). Fish Physiology and Biochemistry 1, 85-92. Bergot, F. (1979). Aquaculture 18, 157-167.

Bergot, F. \& Breque, J. (1983). Aquaculture 34, 203-212.

Bligh, E. G. \& Dyer, W. G. (1959). Canadian Journal of Biochemistry and Physiology 37, 911-917.

Buhler, D. R. \& Halver, J. E. (1961). Journal of Nutrition 74, 307-318.

Cho, C. Y., Slinger, S. J. \& Bayley, H. S. (1982). Comparative Biochemistry and Physiology 73B, 2541.

Clegg, K. M. (1956). Journal of the Science of Food Agriculture 7, 40-44.

Davidson, J., McDonald, I. \& Williams, R. B. (1957). Journal of the Science of Food Agriculture 8, $173-182$.

Fraps, G. S. \& Carlyle, E. C. (1942). Texas Agriculture Experimental Station Bulletin 625, 1-51.

Hill, F. W. \& Andersen, D. L. (1958). Journal of Nutrition 64, 587-603.

Hilton, J. W. (1982). Journal of Fish Biology 20, 69-78.

Hilton, J. W. \& Atkinson, J. L. (1982). British Journal of Nutrition 47, 597-607.

Hilton, J. W., Atkinson, J. L. \& Slinger, S. J. (1982). Canadian Journal of Fisheries and Aquatic Sciences 39, 1229-1234.

Hilton, J. W., Atkinson, J. L. \& Slinger, S. J. (1983). Canadian Journal of Fisheries and Aquatic Sciences 40, $81-85$.

Hilton, J. W., Cho, C. Y. \& Slinger, S. J. (1981). Aquaculture 25, 185-194.

Hilton, J. W. \& Slinger, S. J. (1981). Canadian Special Publication Fisheries and Aquatic Sciences 55, 1-15.

Hilton, J. W. \& Slinger, S. J. (1983). Aquaculture 35, 201-210.

Hilton, J. W. \& Slinger, S. J. (1986). Canadian Journal of Fisheries and Aquatic Sciences 43, 1149-1155.

Horwitz, W. (1980). Official Methods of Analysis of the Association of Analytical Chemists, 13th ed. Washington, DC: Association of Official Analytical Chemists.

Jobling, M. (1983). Journal of Fish Biology 23, 685-703.

Kaushik, J. \& de Oliva Teles, A. (1985). Aquaculture 50, 89-101. 
Luquet, P. (1971). Annales Hydrobiologique 2, 685-703.

Murat, J. C. \& Serfaty, A. (1974). Clinical Chemistry 20, 1576-1577.

National Research Council (1981). Nutritional Energetics of Domestic Animals and Glossary of Energy Terms. Washington, DC: National Academy of Sciences.

Palmer, T. N. \& Ryman, B. E. (1972). Journal of Fish Biology 4, 311-319.

Phillips, A. M. Jr (1969). In Fish Physiology, vol. 1, pp. 18-69 [N. S. Hoar and D. J. Randall, editors]. New York: Academic Press.

Phillips, A. M. Jr (1972). In Fish Nutrition, pp. 1-28 [J. E. Halver, editor]. New York: Academic Press.

Phillips, A. M. Jr, Tunison, A. V. \& Brockway, D. R. (1948). Fisheries Research Bulletin 11, 1-44.

Singh, R. P. \& Nose, T. (1967). Bulletin Freshwater Fisheries Research Laboratory 17, $21-25$.

Smith, R. R. (1971). Progressive Fish-Culturist 33, 132-134.

Spannhof, L. \& Plantikow, H. (1983). Aquaculture 30, 95-108.

Steel, R. G. D. \& Torrie, J. H. (1980). Principles and Procedures of Statistics: A Biometrical Approach, 2nd ed, p. 633. Toronto: McGraw-Hill Book.

Takeuchi, T., Watanabe, T. \& Ogino, C. (1979). Bulletin Japanese Society of Scientific Fisheries 45, $977-982$.

Wilson, R. P. \& Poe, W. E. (1978). Journal of Nuirition 177, 280-286.

Windell, J. T., Folty, J. W. \& Sarakon, J. A. (1978). Progressive Fish-Culturist 40, 51-55. 